\title{
Effect of Cu/Mn-Fortification on In Vitro Activities of the Peptic Hydrolysate of Bovine Lactoferrin against Human Gastric Cancer BGC-823 Cells
}

\author{
Li-Ying Bo ${ }^{1}$, Tie-Jing $\mathrm{Li}^{1, *}$ and Xin-Huai Zhao ${ }^{2, *} \mathbb{C}$ \\ 1 Key Laboratory of Dairy Science, Ministry of Education, Northeast Agricultural University, Harbin 150030, \\ China; Boliying1746@126.com \\ 2 Department of Food Science, Northeast Agricultural University, Harbin 150030, China \\ * Correspondence: tiejingli@163.com (T.-J.L.); zhaoxh@neau.edu.cn or xhzhao63@sina.com.cn (X.-H.Z.); \\ Tel.: +86-451-5519-1813 (X.-H.Z.)
}

Academic Editor: Roberto Fabiani

Received: 24 February 2019; Accepted: 23 March 2019; Published: 27 March 2019

\begin{abstract}
Bovine lactoferrin hydrolysate (BLH) was prepared with pepsin, fortified with $\mathrm{Cu}^{2+}\left(\mathrm{Mn}^{2+}\right)$ 0.64 and $1.28(0.28$ and 0.56$) \mathrm{mg} / \mathrm{g}$ protein, and then assessed for their activity against human gastric cancer BGC-823 cells. BLH and the four fortified BLH products dose- and time-dependently had growth inhibition on the cells in both short- and long-time experiments. These samples at dose level of $25 \mathrm{mg} / \mathrm{mL}$ could stop cell-cycle progression at the G0/G1-phase, damage mitochondrial membrane, and induce cell apoptosis. In total, the fortified BLH products had higher activities in the cells than BLH alone. Moreover, higher $\mathrm{Cu} / \mathrm{Mn}$ fortification level brought higher effects, and $\mathrm{Mn}$ was more effective than $\mathrm{Cu}$ to increase these effects. In the treated cells, the apoptosis-related proteins such as Bad, Bax, p53, cytochrome c, caspase-3, and caspase-9 were up-regulated, while Bcl-2 was down-regulated. Caspase-3 activation was also evidenced using a caspase-3 inhibitor, z-VAD-fmk. Thus, $\mathrm{Cu}$ - and especially Mn-fortification of BLH brought health benefits such as increased anti-cancer activity in the BGC-823 cells via activating the apoptosis-related proteins to induce cell apoptosis.
\end{abstract}

Keywords: lactoferrin hydrolysate; copper; manganese; gastric cancer cells; anti-cancer activity; molecular mechanism

\section{Introduction}

Dietary proteins provide both essential amino acids and energy for the body, and also have several health benefits by the release of so-called bioactive peptides [1], because these peptides have various physiological functions such as anti-cancer, anti-hypertensive, anti-oxidant, mineral-binding, and other effects [2,3]. The solid fraction from yogurt exerts growth inhibition on initial tumor cells, while the peptide fraction from algae protein has anti-cancer activity against the gastric cancer AGS cells through arresting the cells in the post-G1-phase [4,5]. An important Fe-binding protein lactoferrin (LF) and its derivatives have also been assessed for their bio-activities. LF and a LF derivative lactoferricin $B$ have anti-cancer activities in the gastric cancer SGC-7901, AGS cells and oral squamous cell carcinoma [6-8]. Lactoferricin B is also well-known for its anti-bacterial effect against a wide variety of Gram-positive and Gram-negative bacteria $[9,10]$. From a chemical point of view, proteins have various functional groups such as $-\mathrm{OH},-\mathrm{SH},-\mathrm{NH}$, etc., and thus can interact with some macro-elements and trace elements, resulting in changed nutritive values and bio-activities. For LF, Cu supplementation increases immuno-modulation in both murine splenocytes and RAW264.7 macrophages, while Fe addition can enhance growth inhibition and apoptosis induction in the HepG2 cells infected with HBV [11,12]. LF in the stomach is digested by a proteolytic enzyme pepsin; after that, the yielded LF hydrolysate 
might also have opportunity to interact with other dietary components including those multivalent trace metal ions. To the best of our knowledge, very few data are available on the effect of interaction between LF hydrolysate and trace metals on anti-cancer activity of LF hydrolysate in some cancer cells, and such study clearly deserves consideration in the scientific community.

Both $\mathrm{Cu}$ and $\mathrm{Mn}$ are commonly regarded as essential elements to the body. Cu plays crucial roles in the functions of proteins and many enzymes involved in energy metabolism, DNA synthesis, and respiration [13]. For example, $\mathrm{Cu}$ is a critical cofactor of the well-known superoxide dismutase and cytochrome oxidase [14]. Mn is also necessary for a series of physiological processes such as the metabolism of carbohydrates, lipids, and amino acids, and has important role as the cofactor of several enzymes in metabolism in the brain [15]. Both $\mathrm{Cu}^{2+}$ and $\mathrm{Mn}^{2+}$ can complex with some organic materials, which have been studied for their anti-cancer, immune, and anti-oxidant effects [16,17]. Two $\mathrm{Cu}$ complexes can inhibi tumor cell growth, while the Mn complex of N-substituted di(picolyl)amine can inhibit the growth of both U251 and HeLa cells via interfering with mitochondrial functions [18,19]. When LF hydrolysate in the stomach interacts with $\mathrm{Cu}^{2+}$ or $\mathrm{Mn}^{2+}$, potential changes in its activity against gastric cancer BGC-823 cells are promising. However, to the best of our knowledge, these changes are still not assessed.

In our previous study [20], we used the well-differentiated gastric cancer AGS cells as model cells to evaluate the effects of $\mathrm{Cu}^{2+}$ and $\mathrm{Mn}^{2+}$ fortification on anti-cancer activity of a peptic bovine lactoferrin hydrolysate (namely BLH). Both $\mathrm{Cu}$ - and Mn-fortification were evident to increase BLH's anti-cancer activity against the AGS cells, through two events: enhanced apoptosis induction and autophagy inhibition. However, it is regarded that higher degree of cancer cell differentiation generally accompanies lower degree of malignancy. The low-differentiated gastric cancer cells thus deserve another investigation. In the present study, the low-differentiated gastric cancer BGC-823 cells were used as model cells. BLH was also fortified with $\mathrm{CuCl}_{2}$ and $\mathrm{MnSO}_{4}$ of two levels, and then they were assessed and compared for their anti-cancer activity changes using growth inhibition, cell-cycle arrest, mitochondrial membrane disruption, and apoptosis induction as evaluation indices. Furthermore, expression changes of several apoptosis-related proteins were assayed to disclose possible molecular mechanism responsible for the anti-cancer activity changes of the $\mathrm{Cu} / \mathrm{Mn}$-fortified BLH.

\section{Results}

\subsection{Chemical Features of LF, BLH, and Mixtures I-IV}

In this study, the used bovine LF and BLH had protein contents of about 957.3 and $923.4 \mathrm{~g} / \mathrm{kg}$, and Fe contents of about 140.6 and $130.3 \mathrm{mg} / \mathrm{kg}$ (Table 1), respectively. Compared with bovine LF, BLH had higher $-\mathrm{NH}_{2}$ content (0.93 versus $0.49 \mathrm{mmol} / \mathrm{g}$ protein), due to the conducted peptic digestion. $\mathrm{BLH}$ was also measured with a $\mathrm{DH}$ value of $5.1 \pm 0.1 \%$. Due to $\mathrm{Cu} / \mathrm{Mn}$ fortification, the prepared BLF-Cu mixtures (i.e., Mixtures I-II) or BLF-Mn mixtures (i.e., Mixtures III-IV) in this study contained more $\mathrm{Cu}$ or $\mathrm{Mn}$ than BLH. Thus, activity changes of these mixtures in the assessed BGC-823 cells mainly arose from the fortified $\mathrm{Cu}$ or $\mathrm{Mn}$ ions.

Table 1. Chemical features of the bovine LF and prepared BLH (dry basis).

\begin{tabular}{ccccc}
\hline Samples & Protein $\mathbf{( g / k g )}$ & $\begin{array}{c}-\mathbf{N H}_{\mathbf{2}} \text { (mmol/g } \\
\text { Protein) }\end{array}$ & $\begin{array}{c}\text { Degree of } \\
\text { Hydrolysis (\%) }\end{array}$ & Fe (mg/kg) \\
\hline LF & $957.3 \pm 3.1$ & $0.49 \pm 0.01$ & 0 & $140.6 \pm 2.8$ \\
\hline BLH & $923.4 \pm 2.7$ & $0.93 \pm 0.03$ & $5.1 \pm 0.1$ & $130.3 \pm 3.3$ \\
\hline
\end{tabular}

\subsection{Growth Inhibition of BLH and Mixtures I-IV on the BGC-823 Cells}

In this study, 5-FU as positive control could obviously inhibit the growth of BGC-823 cells: at $200 \mu \mathrm{mol} / \mathrm{L}$, it resulted in growth inhibition values of 43.5 (24 h) and 58.7\% (48 h) (Figure 1). BLH 
and its mixtures also exerted growth inhibition on the cells (Figure 1). BLH time- and dose-dependently showed growth inhibition values of 5.3-44.7\%. Mixtures I-IV also time- and dose-dependently inhibited cell growth, and were more effective than BLH, bringing increased growth inhibition values ranging from $6.3 \%$ to $84.5 \%$. Mixtures III-IV showed higher inhibition on the cells than Mixtures I-II (growth inhibition values 11.3-84.5\% versus 6.3-62.3\%). It was also seen that Mixture I (or Mixture III) had weaker growth inhibition than Mixture II (or Mixture IV), based on these measured growth inhibition values. These results indicated that it was the fortified $\mathrm{Cu}$ and especially $\mathrm{Mn}$ conferred $\mathrm{BLH}$ with higher growth inhibition on the cells, while higher $\mathrm{Cu} / \mathrm{Mn}$ fortification levels led to higher inhibitory effect. All assessed samples at dose levels other than $25 \mathrm{mg} / \mathrm{mL}$ gave too weak or too strong growth inhibition on the cells; thus, they were only used at $25 \mathrm{mg} / \mathrm{mL}$ with treatment time of $24 \mathrm{~h}$ in later assays.
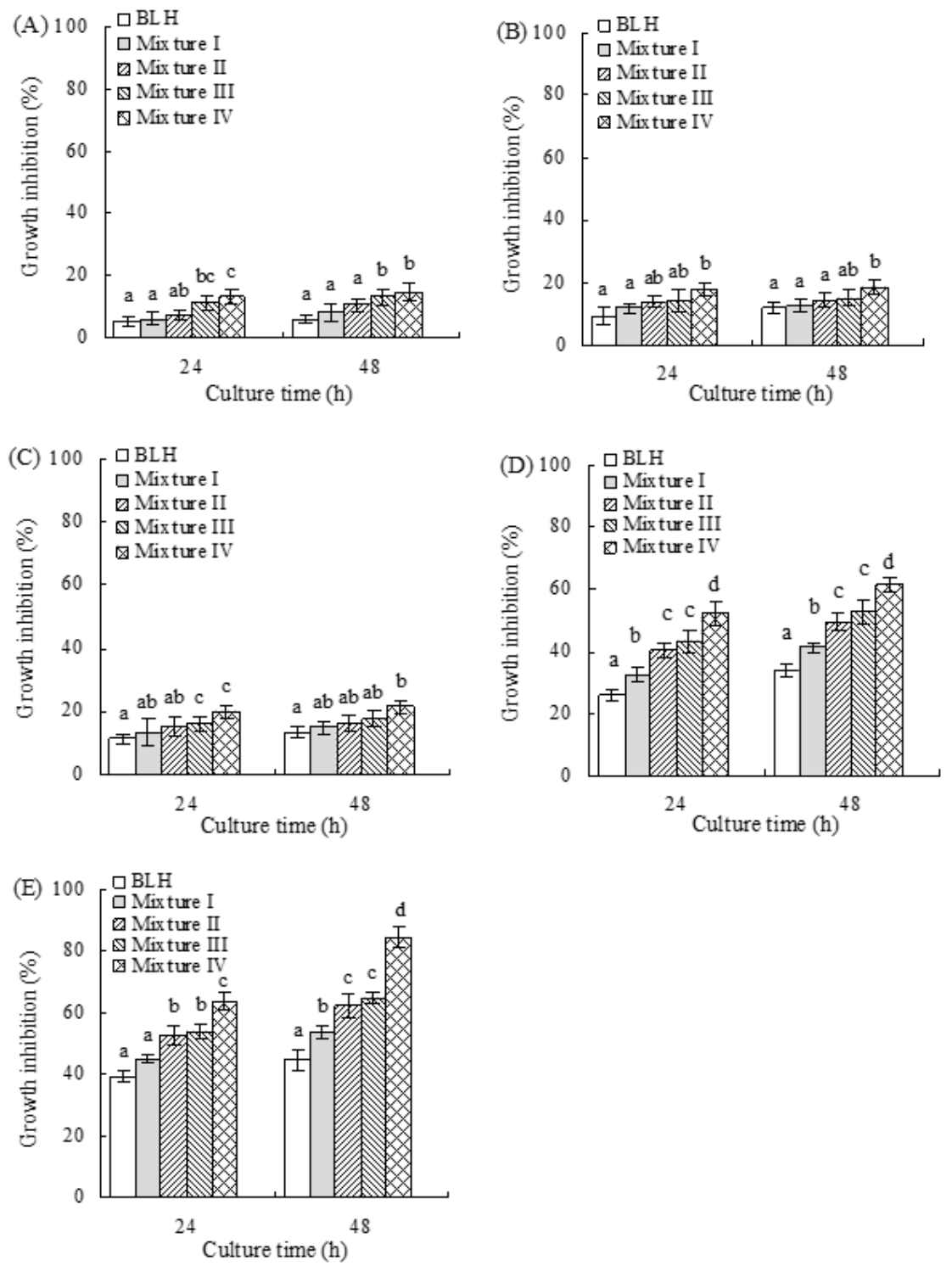

Figure 1. Growth inhibition of BLH and Mixtures I-IV at five dose levels on the BGC-823 cells with treatment times of 24 and $48 \mathrm{~h}$. Mixtures I-II represent bovine lactoferrin hydrolysate (BLH) fortified with $\mathrm{Cu}^{2+}$ at 0.64 and $1.28 \mathrm{mg} / \mathrm{g}$ protein, while Mixtures III-IV represent BLH fortified with $\mathrm{Mn}^{2+}$ at 0.28 and $0.56 \mathrm{mg} / \mathrm{g}$ protein, respectively. (A-E) The mixtures were used at concentrations of 10, 15, 20,25 , and $30 \mathrm{mg} / \mathrm{mL}$, respectively. Different letters like a, b, c, and d above the columns in the same culture time show that the means of different groups were significantly different $(p<0.05)$ by one-way analysis of variance. 
When BLH and Mixtures I-IV were used at dose level of $25 \mathrm{mg} / \mathrm{mL}$ to assay their long-term growth inhibition on the cells (10 and 20 days), the results showed that Mixtures I-IV also had higher anti-proliferative effects on the cells than BLH (Figure 2). Based on the observed sizes and numbers of cell colonies, it was evident that Mixtures III-IV possessed higher activity than Mixtures I-II, while Mixture IV (or Mixture II) had higher effect than Mixture III (or Mixture I). That is, Mn was more effective than $\mathrm{Cu}$ to enhance long-term growth inhibition of $\mathrm{BLH}$, and higher $\mathrm{Cu} / \mathrm{Mn}$ fortification levels also resulted in higher long-term anti-proliferation.
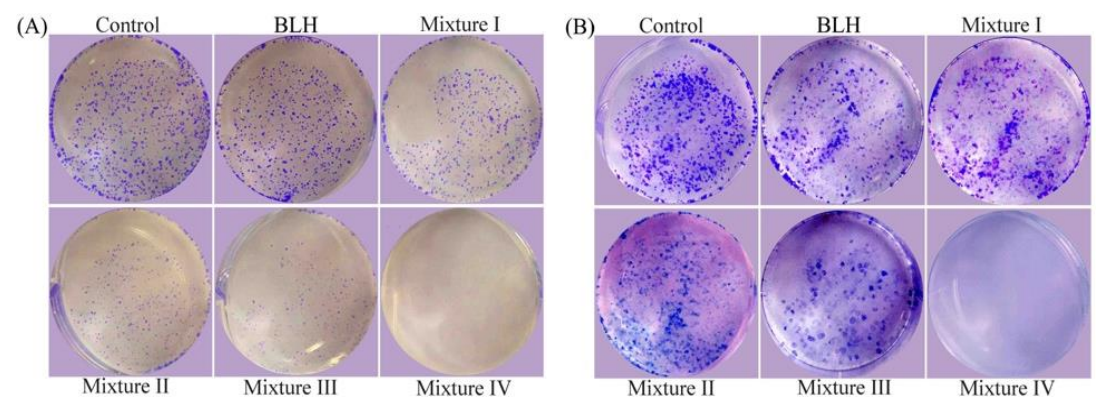

Figure 2. Long-term anti-proliferation of BLH and Mixtures I-IV on the BGC-823 cells with culture times of: 10 days (A); and 20 days (B).

\subsection{Effects of BLH and Mixtures I-IV on Cell-Cycle Progression of the BGC-823 Cells}

To further investigate whether BLH and Mixtures I-IV might cause cell growth inhibition via disturbing cell-cycle progression, flow cytometry analysis was done to detect cell-cycle distribution. Mixtures I-IV with treatment time of $24 \mathrm{~h}$ resulted in higher cell proportions at the G0/G1-phase than BLH did (63.1-69.3\% versus 61.2\%) (Figure 3). Of note, the cells treated by Mixtures I-II or Mixtures III-IV had different G0/G1-phase proportions (63.1-65.6\% versus 67.5-69.3\%). Mixtures I-IV were thus more efficient than BLH to arrest cell-cycle progression at the G0/G1-phase. Overall, $\mathrm{Mn}$ fortification led to greater cell-cycle arrest than $\mathrm{Cu}$ fortification, and higher $\mathrm{Cu} / \mathrm{Mn}$ fortification level caused greater cell-cycle arrest at the G0/G1-phase. It is thus concluded that Cu and especially Mn endowed BLH with higher ability to stop cell-cycle progression at the G0/G1-phase, and thereby caused cell growth inhibition.
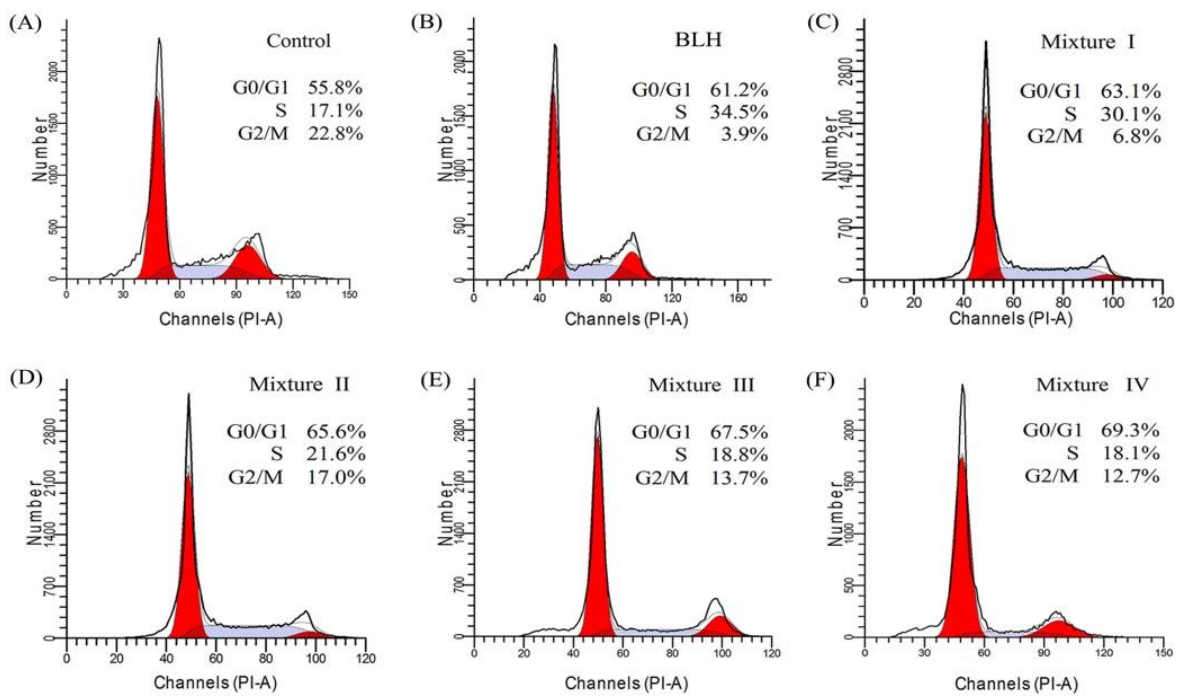

Figure 3. Cell-cycle distribution of the BGC-823 cells: without any treatment (A); or treated with BLH (B) and Mixtures I-IV (C-F) at dose level of $25 \mathrm{mg} / \mathrm{mL}$. 


\subsection{Apoptosis Induction of BLH and Mixtures I-IV to the BGC-823 Cells}

The classic Hoechst 33258 staining was used to observe the morphologic features of the BGC-823 cells exposed to BLH and Mixtures I-IV with treatment time of $24 \mathrm{~h}$ (Figure 4), to further disclose briefly if these samples had potential apoptosis induction to the cells. The control cells without any sample treatment had many cells in the observation vision; moreover, most of the control cells were observed to be dimly blue but only a few cells were apoptotic cells (Figure 4A). The cells exposed to BLH and especially Mixtures I-IV had decreased cell numbers in the observation vision, and increased numbers of apoptotic cells (brilliant blue together with chromatin condensation and nuclear fragmentation) were also observed (Figure 4B-F). These results suggest that BLH and Mixtures I-IV could cause cell apoptosis.
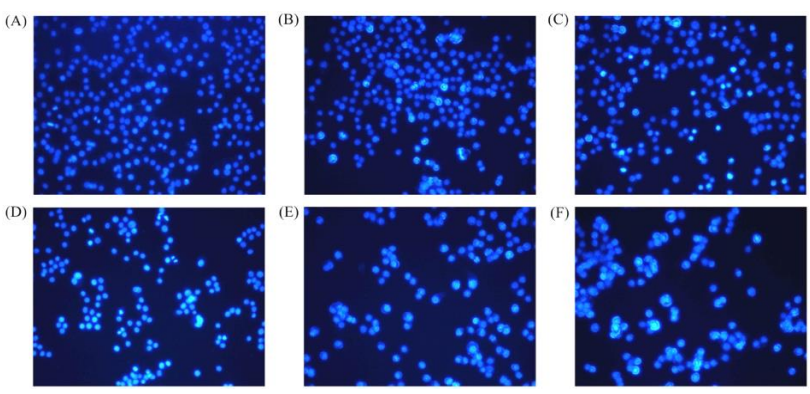

Figure 4. Observed morphology of the BGC-823 cells: without any treatment (A); or treated with BLH (B) and Mixtures I-IV (C-F) at dose level of $25 \mathrm{mg} / \mathrm{mL}$ by a fluorescence microscope at $200 \times$ magnification.

Apoptosis induction of BLH and Mixtures I-IV in the BGC-823 cells was then assayed by the classic flow cytometry technique, based on measured total apoptotic cell proportions (i.e., Q2 + Q4). The results (Figure 5) show that these samples all had apoptosis induction in the treated cells. The control cells had total apoptotic proportion of $4.3 \%$. The cells exposed to Mixtures I-IV showed higher total apoptotic proportions $(28.6 \%, 33.2 \%, 40.7 \%$, and $42.7 \%$, respectively) than those exposed to BLH alone (25.3\%). Mixture IV (or Mixture II) more obviously caused cell apoptosis than Mixture III (or Mixture I). It was thus proposed that $\mathrm{Mn}$ fortification was more effective than $\mathrm{Cu}$ fortification to endow BLH with higher apoptosis induction, and higher $\mathrm{Cu} / \mathrm{Mn}$ fortification level also brought higher activity. For these assessed samples, the order of apoptosis induction was completely consistent with the order of cell-cycle arrest (Figure 5), suggesting that both apoptosis induction and cell-cycle arrest contributed to the assayed growth inhibition.
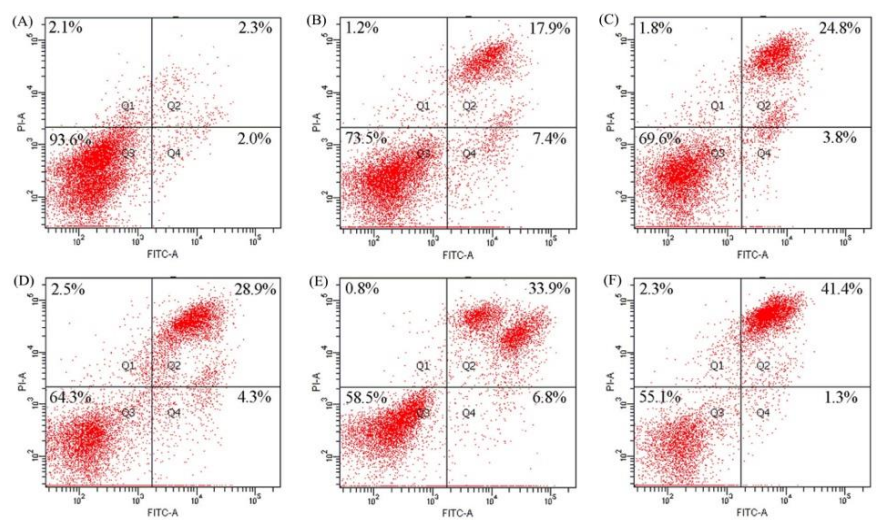

Figure 5. Cell proportions of the BGC-823 cells: without any treatment (A); or treated with BLH (B) and Mixtures I-IV (C-F) at dose level of $25 \mathrm{mg} / \mathrm{mL}$. Q1-Q4 represent necrotic, late apoptotic, intact, and early apoptotic cells, respectively. 


\subsection{Mitochondrial Membrane Disruption of the BGC-823 Cells by BLH and Mixtures I-IV}

Mitochondrial membrane potential (MMP) of the BGC-823 cells exposed to BLH and Mixtures I-IV were analyzed using flow cytometry and JC-1 dye staining, to further verify whether the treated cells had mitochondrial dysfunction. The cells treated by BLH had decreased MMP (cell proportion of red fluorescence $84.6 \%$, Figure $6 \mathrm{~B}$ ), compared with the control cells without sample treatment (95.5\%, Figure 6A). Moreover, the cells treated with Mixtures III-IV had lower cell proportions of red fluorescence $(68.7 \%$ and $62.8 \%$, Figure $6 \mathrm{E}, \mathrm{F})$ than those treated with Mixtures I-II (red fluorescence of $78.8 \%$ and $71.6 \%$, Figure 6C,D). Mixtures I-II and especially Mixtures III-IV thereby brought greater MMP loss in the treated cells. It was thus demonstrated that these samples caused mitochondrial membrane disruption, and then led to the release of cytochrome $\mathrm{c}$ to trigger cell apoptosis. It was also seen from these measured data that $\mathrm{Mn}$ fortification was more efficient than $\mathrm{Cu}$ fortification to induce MMP loss, and higher $\mathrm{Cu} / \mathrm{Mn}$ fortification levels brought increased MMP loss.
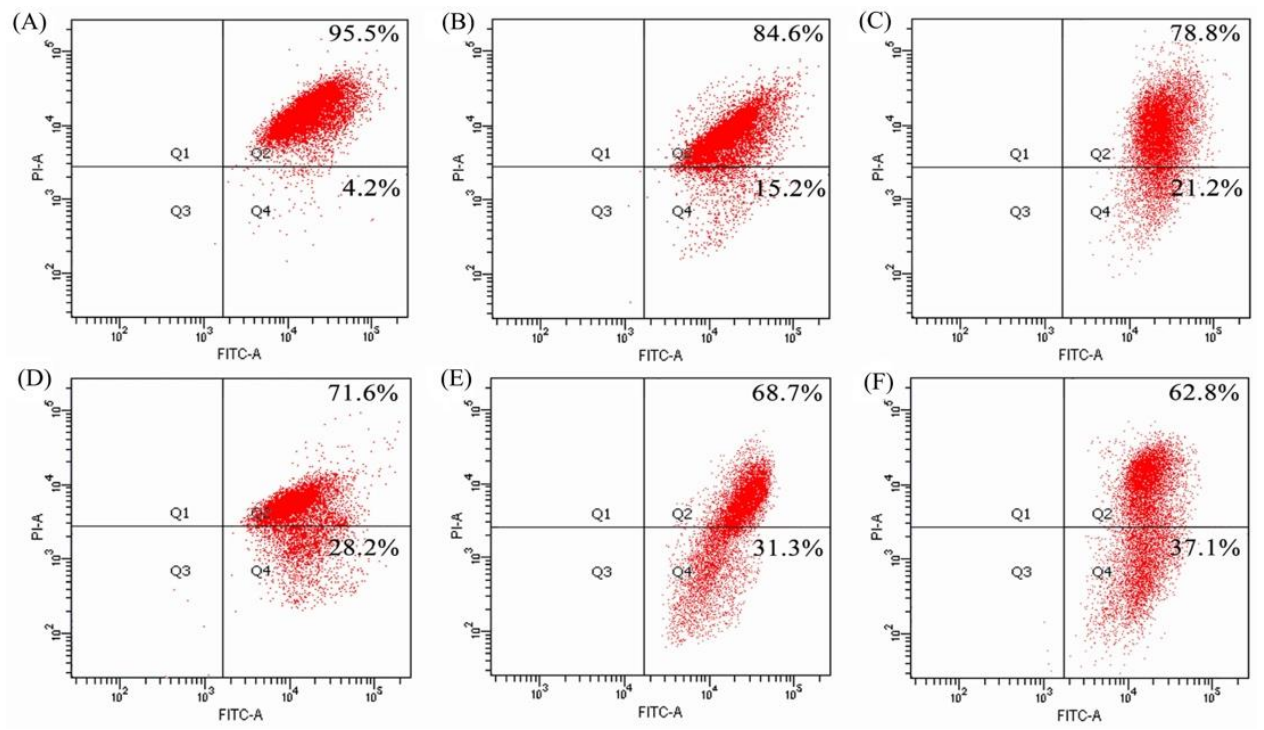

Figure 6. MMP loss of the BGC-823 cells: without any treatment (A); or treated with BLH (B) and Mixtures I-IV (C-F) at dose level of $25 \mathrm{mg} / \mathrm{mL}$.

\subsection{Expression Changes of Apoptosis-related Proteins in the BGC-823 Cells}

Serial Western-blot assays were done to evaluate expression levels of seven proteins in the treated cells that have been classified as apoptosis-related proteins. In total, BLH and Mixtures I-IV in the cells could up-regulate Bax, Bad, p53, and cytochrome c expression and down-regulate Bcl-2 expression, together with caspase- 3 and caspase- 9 activation; however, these samples did not cause clear change in caspase-8 expression (Figure 7A). Mn fortification was more efficient than $\mathrm{Cu}$ fortification to regulate the expression of these proteins. Mixtures I-IV thus had enhanced anti-cancer activities against the BGC-823 cells than BLH alone, mainly via mediating the expression of these apoptosis-related proteins. Using the caspase-3 inhibitor z-VAD-fmk in the cells could provide further evidence (Figure 7B). When the cells were treated by the z-VAD-fmk, Mixture II and especially Mixture IV showed the ability to increase the expression of Bad (relative expression folds 1.29 and 1.30 vs. 1.15) and Bax (relative expression folds 1.23 and 1.96 vs. 1.18). These results suggest that both Mixture II and Mixture IV indeed were able to induce caspase-3 activation or cell apoptosis. BLH and Mixtures I-IV were thus suggested to induce cell apoptosis via the caspase-3-dependent pathway (Figure 8). 

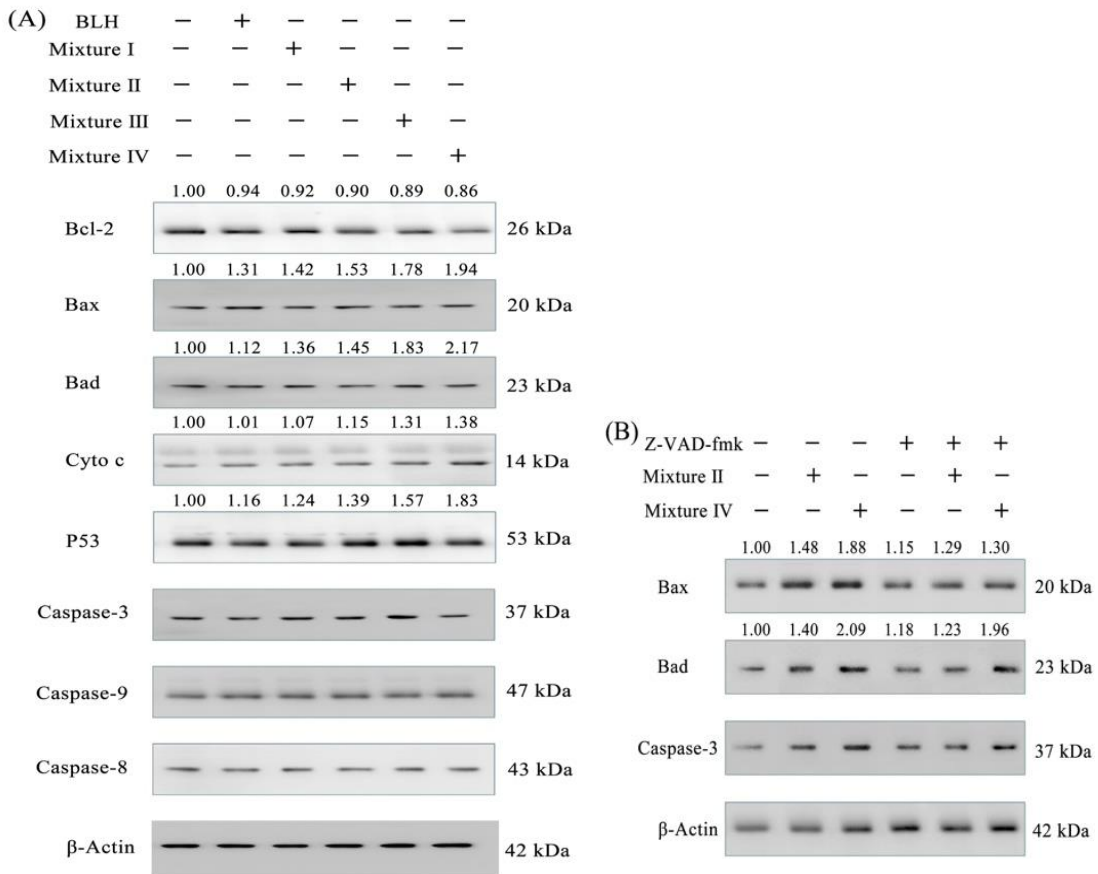

Figure 7. Expression changes of the apoptosis-related proteins in the BGC-823 cells treated with BLH and the Mixtures I-IV (A), respectively or treated with Mixture II or Mixture IV in the absence or presence of a caspase-3 inhibitor z-VAD-fmk (B).

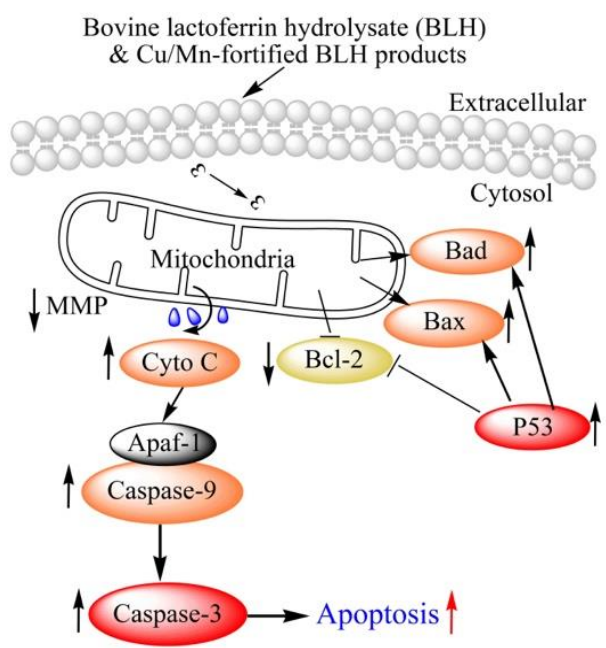

Figure 8. Proposed mechanism responsible for apoptosis induction of BLH and its $\mathrm{Cu} / \mathrm{Mn}$ mixtures.

\section{Discussion}

Food hydrolysates possess in vitro anti-cancer activities to many cancer cells such as PC-3, DU-145, $\mathrm{H}-1299$, and Hela cells [21-23]. Bovine LF as one of the most important bioactive proteins in milk has anti-cancer activity to cancer cells, but is regarded to be harmless to normal cells [24-26]. It has been demonstrated that bovine BLH has growth inhibition in gastric cancer and oral squamous cell carcinoma [7,8], can inhibit metastasis of liver and lung cancer cells in the mice [27], and displays anti-cancer effects in colon cancer cells [28]. In this study, BLH and the $\mathrm{Cu} / \mathrm{Mn}$-fortified Mixtures I-IV all had anti-cancer activities against the BGC-823 cells with clear growth inhibition, cell-cycle block, and apoptosis induction. The present results are thus consistent with the reported ones. When BLH was fortified with $\mathrm{Cu}$ or $\mathrm{Mn}$ ions, the resultant mixtures had enhanced anti-cancer effects in the cells. Similarly, the Fe-fortified bovine LF has enhanced growth inhibition on the HepG2 cells infected 
with HBV [12]. Two previous studies also verify that catechin, epicatechin, epigallocatechin, and particularly epigallacatechin-3-gallate in the presence of $\mathrm{Cu}$ can induce apoptosis of a breast cancer cell line MDA-MB-231 [29,30]. It is reasonable that the fortified $\mathrm{Cu} / \mathrm{Mn}$ contributed these enhanced effects. Mn was always more efficient than $\mathrm{Cu}$ to increase these measured effects, which is important but was unsolved in the present study.

In general, protein hydrolysates exert anti-cancer effects via different pathways including anti-proliferation, cell-cycle arrest, apoptosis induction, and others. Rapid growth of cancer cells is achieved by cell continuous division, while cell-cycle is a programmed process of cell division. Thus, stopping cell-cycle progression at a certain cell phase is an important way to inhibit the growth of cancer cells [31]. The hydrolysates derived from donkey milk thus can arrest cell-cycle progression of human lung cancer A549 cells at the G0/G1-phase, while those from roe also can arrest cell-cycle of human oral cancer cells Ca9-22 and CAL27 at the sub-G1-phase [32,33]. Meanwhile, cell apoptosis is a critical mechanism of programmed cell death and, therefore, the induced cell apoptosis is a promising strategy for cancer treatment [34]. Protein hydrolysates derived from giant grouper (Epinephelus Lanceolatus) can induce apoptosis of human oral cancer cells, while those from tuna cooking juice induce apoptosis in human breast cancer MCF-7 cells [33,35]. These mentioned findings all support that BLH and Mixtures I-IV had cell-cycle arrest and apoptosis induction, and thereby led to growth inhibition in the cells.

In this study, the treated cells had changed morphologic features and especially MMP loss. This fact suggests potential disruption of mitochondrial membrane and subsequently release of cytochrome c. BLH and Mixtures I-IV thus could induce the apoptosis of the BGC-823 cells via the classic caspase-3-dependent pathway (or mitochondrial pathway). Cytochrome c released (a positive event of cell apoptosis) from the mitochondria into the cytosol activates Apaf-1 and caspase-9, leading to caspase-3 activation and thereby cell apoptosis [36]. Apoptosis of cancer cells requires effective activation of a tumor suppressor p53 [37]. P53 is able to up-regulate pro-apoptotic proteins Bax and Bad, resulting in the increased permeability of mitochondrial membrane, cytochrome $c$ release, and the activation of apoptogenic factors apaf-1. However, another anti-apoptotic protein Bcl-2 has a function to reduce cytochrome c release, which can be suppressed by p53 [38]. The peptides from rapeseed can up-regulate p53 and Bax but down-regulate Bcl-2 expression in HepG2 cells, while rice protein hydrolysates can induce $\mathrm{H} 9 \mathrm{c} 2$ myocardiocytes apoptosis through the Bcl-2/Bax pathway [39,40]. More importantly, a previous study demonstrating a short-term cooperation of 3,4-dihydroxy-trans-stilbene and exogenous $\mathrm{Cu}$ also showed preferential apoptosis induction of HepG2 cells via mitochondria apoptosis pathway [41]. In this study, these assessed samples up-regulated the pro-apoptotic proteins Bad, Bax, and p53 but down-regulated the anti-apoptotic protein Bcl-2, and then increased cytochrome c release in the cytosol, which subsequently triggered the activation of caspase- 9 and caspase- 3 as well as cell apoptosis. However, caspase- 8 expression, which represents the activation of the extrinsic apoptosis pathway, had no significant change in the cells (Figures 6 and 7). This fact demonstrated that BLH and its fortified mixtures only activated the intrinsic but not extrinsic apoptosis pathway in the BGC-823 cells. Z-VAD-fmk as a classic caspase-3 inhibitor can suppress caspase-3 activation and inhibit the thapsigargin-induced cell death in human breast cancer cells MDA-MB-468 [42]. In this study, both Mixture II and Mixture IV decreased the suppression of z-VAD-fmk on caspase-3 activation via enhancing Bad and Bax expression (Figure 6), verifying that the disclosed apoptosis mechanism indeed was a caspase-3-dependent pathway. Mixtures I-II and especially Mixtures III-IV led to greater expression regulation on these apoptosis-related proteins than BLH did, and therefore exerted higher anti-cancer activity in the cells. However, whether BLH and the fortified mixtures could display anti-cancer effects via other pathways or mechanisms should be disclosed in the future. Moreover, whether these samples might have anti-cancer effects on other cancer cells is still unsolved. 


\section{Materials and Methods}

\subsection{Materials}

Bovine LF was purchased from MILEI Gmbh (Leutkirch, Germany). The Dulbecco's modified Eagle's medium (DMEM) and porcine gastric mucosa pepsin (CAS: 9001-75-6) were purchased from Sigma-Aldrich Co. Ltd. (St. Louis, MO, USA), while the fetal bovine serum (FBS) was bought from Wisent Inc. (Montreal, QC Canada). Dextran T-70, phosphate-buffered saline (PBS), and Hoechst 33258 dye were bought from Solarbio Science and Technology Co. Ltd. (Beijing, China). 5-Fluorouracil (5-FU) was bought from Jinyao Pharmaceutical Co. Ltd. (Tianjin, China). Annexin V-FITC Apoptosis Detection Kit, Cell Cycle Analysis Kit, BCA Protein Assay Kit, RIPA Lysis Buffer, Hoechst 33258 dye, crystal violet dye, JC-1 dye, and phenylmethanesulfonyl fluoride (PMSF) were all purchased from Beyotime Institute of Biotechnology (Shanghai, China). Cell Counting Kit-8 (CCK-8) was bought from Dojindo Molecular Technologies, Inc. (Kyushu, Japan). Caspase-3 inhibitor z-VAD-fmk, primary anti-bodies ( $\beta$-actin, caspase-3, caspase-9, caspase-8, Bad, Bax, p53, cytochrome $c$, and Bcl-2), and secondary anti-body were bought from Cell Signaling Technology, Inc. (Boston, MA, USA). Other chemicals used in this study were analytical grade. Ultrapure water was generated from Milli-Q Plus (Millipore Corporation, New York, NY, USA), and used in this study.

The BGC-823 cells were purchased from Cell Bank of the Chinese Academy of Sciences (Shanghai, China), and cultured at $37^{\circ} \mathrm{C}$ in the DMEM with $10 \%$ FBS, 100 units $/ \mathrm{mL}$ penicillin, and $100 \mu \mathrm{g} / \mathrm{mL}$ streptomycin, using a humidified incubator with $5 \% \mathrm{CO}_{2}$.

\subsection{Sample Preparation}

BLH was prepared as previously described [43]. In brief, $5.0 \mathrm{~g}$ bovine LF was dissolved in $100 \mathrm{~mL}$ water, adjusted to $\mathrm{pH} 2.5$ using $1 \mathrm{~mol} / \mathrm{L} \mathrm{HCl}$, added with pepsin of 750 units $/ \mathrm{g}$ protein, $\operatorname{kept}$ at $37^{\circ} \mathrm{C}$ for $4 \mathrm{~h}$, heated at $80^{\circ} \mathrm{C}$ for $15 \mathrm{~min}$ to inactive pepsin, cooled to $20^{\circ} \mathrm{C}$, neutralized to $7.0 \mathrm{using} 1 \mathrm{~mol} / \mathrm{L}$ $\mathrm{NaHCO}_{3}$, and centrifuged at $12,000 \times g$ for $30 \mathrm{~min}$ at $4{ }^{\circ} \mathrm{C}$. The collected supernatant (i.e., BLH) was freeze-dried with a freeze-dryer (ALPHA 1-4 LSCplus, Marin Christ, Osterode, Germany), ground into powder, and then stored at $-20{ }^{\circ} \mathrm{C}$ until use.

$\mathrm{BLH}$ was dissolved in water, and added with $\mathrm{CuCl}_{2}$ (or $\mathrm{MnSO}_{4}$ ) solution to achieve final $\mathrm{Cu}$ (or Mn) levels of 0.64 and 1.28 (or 0.28 and 0.56 ) $\mathrm{mg} / \mathrm{g}$ protein. Mixture I and Mixture II were designated as the $\mathrm{Cu}$-fortified $\mathrm{BLH}$ with 0.64 and $1.28 \mathrm{Cu} \mathrm{mg} / \mathrm{g}$ protein, while Mixture III and Mixture IV were designated as the Mn-fortified BLH with 0.28 and $0.56 \mathrm{Mn} \mathrm{mg/g}$ protein, respectively.

\subsection{Sample Analyses}

The protein contents of the samples were assayed using the Kjidahl method and a conversion factor of 6.38, while Fe content was detected using the $o$-phenanthroline method [44]. The content of free amino groups $\left(-\mathrm{NH}_{2}\right)$ was measured using the $o$-pthaldialdehyde method together with standard L-leucine solutions of $0-36 \mathrm{mg} / \mathrm{mL}$ [45]. Degree of hydrolysis of BLH was calculated as previously described [46]. A spectrophotometer (UV-2401PC, Shimadzu, Kyoto, Japan) was used in these spectrometric analyses.

\subsection{Assay of Cytotoxic Effect}

The cells $\left(2 \times 10^{4}\right.$ cells per well) were seeded in 96-well plates in $100 \mu \mathrm{L}$ medium, and incubated for $24 \mathrm{~h}$. The medium was replaced by $200 \mu \mathrm{L}$ fresh medium containing BLH or Mixtures I-IV at dose levels of $10-30 \mathrm{mg} / \mathrm{mL}$, followed by an incubation of 24 and $48 \mathrm{~h}$ and medium removal. CCK-8 solution of $100 \mu \mathrm{L}(10 \mu \mathrm{L}$ CCK-8 in $90 \mu \mathrm{L}$ medium) was added into each well, followed by another incubation of $1.5 \mathrm{~h}$. Optical density values were measured at $450 \mathrm{~nm}$ with a microplate reader (Bio-Rad Laboratories, Hercules, CA, USA), and used to calculate growth inhibition as previously described [20]. The cells exposed to $200 \mu \mathrm{mol} / \mathrm{L} 5-\mathrm{FU}$ were designed as positive control, while those 
exposed to the media with 5\% FBS were designed as negative control without any growth inhibition (i.e., $100 \%$ viability).

\subsection{Colony Formation Assay}

To evaluate long-term growth inhibition of these samples, the cells $\left(1 \times 10^{3}\right.$ cells per well $)$ were seeded in 6-well plates, and treated with the medium containing the assessed samples at dose level of $25 \mathrm{mg} / \mathrm{mL}$ for $24 \mathrm{~h}$. Then, the medium with $5 \%$ FBS was replaced every 3 days. After an incubation of 10 or 20 days, the cells were fixed with methanol, stained with crystal violet dye, dried overnight, and then photographed with an EOS 6D Canon digital camera (Canon Inc., Tokyo, Japan).

\subsection{Assay of Cell-Cycle Progression}

The cells $\left(1 \times 10^{6}\right.$ cells per dish) were seeded on 100-mm cell culture dish, incubated for $24 \mathrm{~h}$ with $10 \mathrm{~mL}$ medium, treated with $10 \mathrm{~mL}$ per dish fresh medium containing the assessed samples at dose level of $25 \mathrm{mg} / \mathrm{mL}$ for $24 \mathrm{~h}$, harvested, washed twice with the cold PBS (10 mmol/L, pH 7.3), fixed with $70 \%$ cold ethanol by shaking once every 15 min overnight at $4{ }^{\circ} \mathrm{C}$, washed with the cold PBS again, resuspended with binding buffer $(500 \mu \mathrm{L})$, and stained with $10 \mu \mathrm{L}$ RNase A and $25 \mu \mathrm{L}$ propidium iodide (PI) for $30 \mathrm{~min}$ at $37^{\circ} \mathrm{C}$ in the dark. The cells treated with the medium were designated as negative control. Cell proportions in the G0/G1-, S-, and G2/M-phases were measured using a flow cytometer (FACS Calibur, Becton Dickson, San Jose, CA, USA), and analyzed with the ModFit software (Verity Software House, Topsham, ME, USA).

\subsection{Hoechst 33258 Staining}

The cells $\left(1 \times 10^{6}\right.$ cells per well) were seeded in 6-well plates with $2 \mathrm{~mL}$ medium, incubated for 24 $\mathrm{h}$, and treated with medium containing the assessed samples at dose level of $25 \mathrm{mg} / \mathrm{mL}$ for $24 \mathrm{~h}$. After removal of the medium, the cells were fixed by methanol for $5 \mathrm{~min}$, washed twice with PBS, stained with Hoechst 33258 dye for $5 \mathrm{~min}$ in the dark at $22^{\circ} \mathrm{C}$, and observed under a fluorescence microscope (Type Eclipice-Ti-S, Nikon, Japan) with a magnification of $200 \times$.

\subsection{Assay of Mitochondrial Membrane Potential}

Changes of mitochondrial membrane potential (MMP) of the treated cells were detected using the flow cytometer and JC- 1 dye. The cells $\left(5 \times 10^{5}\right.$ cells per well) were seeded in 6-well plates with $2 \mathrm{~mL}$ medium, cultured for $24 \mathrm{~h}$, treated with the medium containing the samples at dose level of $25 \mathrm{mg} / \mathrm{mL}$ for $24 \mathrm{~h}$, harvested, stained with JC- 1 dye at $37^{\circ} \mathrm{C}$ for $20 \mathrm{~min}$, and then measured with the flow cytometer (FACS Calibur, Becton Dickson).

\subsection{Assay of Apoptosis Induction}

The cells $\left(2 \times 10^{4}\right.$ cells per well) were seeded in 6-well plates with $2 \mathrm{~mL}$ medium, and incubated for $24 \mathrm{~h}$. After medium removal, the cells were treated with the medium containing the samples at dose level of $25 \mathrm{mg} / \mathrm{mL}$ for $24 \mathrm{~h}$. The cells treated with the medium consisting of $5 \%$ FBS served as negative control. After that, an AnnexinV-FITC/PI Apoptosis Detection Kit was used according to kit instruction. The cells were harvested, resuspended in $500 \mu \mathrm{L}$ of the Annexin V-FITC binding buffer consisting of $5 \mu \mathrm{L}$ Annexin V-FITC and $10 \mu \mathrm{L}$ PI at $20^{\circ} \mathrm{C}$ for $30 \mathrm{~min}$ in the dark, and assayed by the flow cytometry (FACS Calibur, Becton Dickson) to detect the intact (Q3), early apoptotic (Q4), late apoptotic (Q2), and necrotic $(\mathrm{Q} 1)$ cell proportions.

\subsection{Western-Blot Assay}

The cells $\left(5 \times 10^{6}\right.$ cells per dish) were seeded on 100 -mm cell culture dishes with $10 \mathrm{~mL}$ medium, incubated for $24 \mathrm{~h}$, treated with the medium containing the samples at dose level of $25 \mathrm{mg} / \mathrm{mL}$ for $24 \mathrm{~h}$, harvested by trypsin-EDTA, washed three times with the cold PBS, and lysed on ice for $30 \mathrm{~min}$ 
with $100 \mu \mathrm{L}$ the RIPA Lysis Buffer supplemented with $1 \mathrm{mmol} / \mathrm{L}$ PMSF. The lysate was centrifuged at $12,000 \times g$ at $4{ }^{\circ} \mathrm{C}$ for $5 \mathrm{~min}$. The supernatant was collected as total cellular protein. Then, protein content was measured using the BCA Protein Assay Kit. Protein $(20 \mu \mathrm{g})$ of total protein extracts were separated on a $10-15 \%$ SDS-PAGE gel and transferred to the PVDF membrane. The blots were blocked with $5 \%$ BSA, probed with the primary anti-body (dilution 1:3000) in blocking buffer at $4{ }^{\circ} \mathrm{C}$ overnight. The bands were incubated with the anti-rabbit secondary anti-body horseradish peroxidase conjugate. The enhanced chemiluminescence was covered on the PVDF membrane, and the signal was detected using a Chemi Scope 6300 (Clinx Science Instrument, Shanghai, China).

\subsection{Statistical Analysis}

All data from three independent experiments were analyzed by the SPSS 16.0 software (SPSS Inc., Chicago, IL, USA) and one-way analysis of variance (ANOVA) with Duncan's multiple range tests, and expressed as means or means \pm standard deviations.

\section{Conclusions}

This study found that $\mathrm{Cu}^{2+}$ and especially $\mathrm{Mn}^{2+}$ fortification of a peptic bovine lactoferrin hydrolysate BLH led to desired changes for its in vitro anti-cancer effects on human gastric cancer BGC-823 cells. Compared with BLH itself, the $\mathrm{Cu} / \mathrm{Mn}$ fortified BLH had increased growth inhibition, arrested more cells in the G0/G1-phase, disrupted mitochondrial membrane greatly, and promoted cell apoptosis. Furthermore, $\mathrm{Cu} / \mathrm{Mn}$ fortification led to expression changes of seven apoptosis-related proteins in the cells, and thereby triggered cell apoptosis via the mitochondrial pathway. $\mathrm{Mn}^{2+}$ was always more efficient than $\mathrm{Cu}^{2+}$ to increase these assayed activities, while higher metal level consistently resulted in enhanced activities. Fortification of trace metal ions thus suggests endowing BLH with increased anti-cancer action in the BGC-823 cells.

Author Contributions: L.-Y.B. performed the experiments; T.-J.L. designed the bovine lactoferrin hydrolysis; X.-H.Z. conceived and designed the experiments, and analyzed the data; and L.-Y.B. and X.-H.Z. wrote the paper.

Funding: This research was fund by the Innovative Research Team of Higher Education of Heilongjiang Province (Project No. 2010td11).

Acknowledgments: The authors thank Li-Ling Yue from Qiqihar Medical University for her kindly help in western-blot assay as well as the anonymous referees for their valuable advice.

Conflicts of Interest: The authors declare no conflict of interest.

\section{Abbreviations}

$\begin{array}{ll}\text { BLH } & \text { Bovine lactoferrin hydrolysate } \\ \text { CCK-8 } & \text { Cell counting kit-8 } \\ \text { DMEM } & \text { Dulbecco's modified Eagle's medium } \\ \text { EDTA } & \text { Ethylenediamine tetra-acetic acid } \\ \text { FBS } & \text { Fetal bovine serum } \\ 5 \text {-FU } & \text { 5-Fluorouracil } \\ \text { LF } & \text { Lactoferrin } \\ \text { MMP } & \text { Mitochondrial membrane potential } \\ \text { PBS } & \text { Sodium phosphate buffered solution } \\ \text { PI } & \text { Propidium iodide } \\ \text { PMSF } & \text { Phenylmethanesulfonyl fluoride }\end{array}$




\section{References}

1. Bhat, Z.F.; Kumar, S.; Bhat, H.F. Bioactive peptides of animal origin: a review. J. Food Sci. Tech. 2015, 52, 5377-5392. [CrossRef]

2. Chalamaiah, M.; Kumar, B.D.; Hemalatha, R.; Jyothirmayi, T. Fish protein hydrolysates: proximate composition, amino acid composition, antioxidant activities and applications: a review. Food Chem. 2012, 135, 3020-3038. [CrossRef] [PubMed]

3. García, M.C.; Puchalska, P.; Esteve, C.; Marine, M.L. Vegetable foods: a cheap source of proteins and peptides with antihypertensive, antioxidant, and other less occurrence bioactivities. Talanta 2013, 106, 328-349. [CrossRef]

4. Reddy, G.V.; Friend, B.A.; Shahani, K.M.; Farmer, R.E. Antitumor activity of yogurt components. J. Food Protect. 1983, 46, 8-11. [CrossRef]

5. Sheih, I.C.; Fang, T.J.; Wu, T.K.; Lin, P.H. Anticancer and antioxidant activities of the peptides fraction from algae protein waste. J. Agric. Food Chem. 2010, 58, 1202-1207. [CrossRef] [PubMed]

6. Xu, X.X.; Jiang, H.R.; Li, H.B.; Zhang, T.N.; Zhou, Q.; Liu, N. Apoptosis of stomach cancer cell SGC-7901 and regulation of Akt signaling way induced by bovine lactoferrin. J. Dairy Sci. 2010, 93, 2344-2350. [CrossRef] [PubMed]

7. Pan, W.R.; Chen, P.W.; Chen, Y.L.; Hsu, H.C.; Lin, C.C.; Chen, W.J. Bovine lactoferricin B induces apoptosis of human gastric cancer cell line AGS by inhibition of autophagy at a late stage. J. Dairy Sci. 2013, 96, 7511-7520. [CrossRef] [PubMed]

8. Chea, C.; Miyauchi, M.; Inubushi, T.; Ayuningtyas, N.F.; Subarnbhesaj, A.; Nguyen, P.T.; Shrestha, M.; Haing, S.; Ohta, K.; Takata, T. Molecular mechanism of inhibitory effects of bovine lactoferrin on the growth of oral squamous cell carcinoma. PLoS ONE 2018, 13, 1-19. [CrossRef] [PubMed]

9. Wakabayashi, H.; Bellamy, W.; Takase, M.; Tomita, M. Inactivation of Listeria monocytogenes by lactoferricin, a potent antimicrobial peptide derived from cow's milk. J. Food Protect. 1992, 55, 238-240. [CrossRef]

10. Shin, K.; Yamauchi, K.; Teraguchi, S.; Hayasawa, H.; Tomita, M.; Otsuka, Y.; Yamazak, S. Antibacterial activity of bovine lactoferrin and its peptides against Enterohaemorrhagic Escherichia coli O157: H7. Lett Appl. Microbiol. 1998, 26, 407-411. [CrossRef]

11. Zhao, H.J.; Zhao, X.H. Modulatory effect of the supplemented copper ion on in vitro activity of bovine lactoferrin to murine splenocytes and RAW264.7 macrophages. Biol. Trace Res. 2018. [CrossRef]

12. Li, S.T.; Zhou, H.B.; Huang, G.R.; Liu, N. Inhibition of HBV infection by bovine lactoferrin and iron-, zinc-saturated lactoferrin. Med. Microbiol. Immun. 2009, 198, 19-25. [CrossRef]

13. Bogden, J.D. The Essential Trace Elements and Minerals; Humana Press: Totowa, NJ, USA, 2000.

14. Mertz, W. The essential trace elements. Science 1981, 1213, 1332-1338. [CrossRef]

15. Nordberg, M.; Nordberg, G.F. Trace element research-historical and future aspects. J. Trace Elem. Med. Biol. 2016, 38, 46-52. [CrossRef] [PubMed]

16. Beard, J.L. Iron biology in immune function, muscle metabolism and neuronal functioning. J. Nutr. 2001, 131, 568-579. [CrossRef] [PubMed]

17. Tisato, F.; Marzano, C.; Porchia, M.; Pellei, M.; Santini, C. Copper in diseases and treatments, and copper-based anticancer strategies. Med. Res. Rev. 2010, 30, 708-749. [CrossRef] [PubMed]

18. Leng, J.; Shang, Z.M.; Quan, Y. High energy transition state complex increased anticancer activity: a case study on $\mathrm{Cu}^{\mathrm{II}}$-complexes. Inorg. Chem. Commun. 2018, 91, 119-123. [CrossRef]

19. Zhou, D.F.; Chen, Q.Y.; Qi, Y.; Fu, H.J.; Li, Z.; Zhao, K.D.; Gao, J. Anticancer activity, attenuation on the absorption of calcium in mitochondria, and catalase activity for manganese complexes of N-substituted di(picolyl)amine. Inorg. Chem. 2011, 50, 6929-6937. [CrossRef] [PubMed]

20. Bo, L.Y.; Li, T.J.; Zhao, X.H. Copper or magnesium supplementation endows the peptic hydrolysate from bovine lactoferrin with enhanced activity to human gastric cancer AGS cells. Bio. Trace Elem. Res. 2018, 1-11.

21. Duarte, D.C.; Nicolau, A.; Teixeira, J.A.; Rodrigues, L.R. The effect of bovine milk lactoferrin on human breast cancer cell lines. J. Dairy Sci. 2011, 94, 66-76. [CrossRef]

22. Chi, C.F.; Hu, F.Y.; Wang, B.; Li, T.; Ding, G.F. Antioxidant and anticancer peptides from the protein hydrolysate of blood clam (Tegillarca granosa) muscle. J. Funct. Foods 2015, 15, 301-313. 
23. Pan, X.; Zhao, Y.Q.; Hu, F.Y.; Chi, C.F.; Wang, B. Anticancer activity of hexapeptide from skate (Raja porosa) cartilage protein hydrolysate in Hela cells. Mar. Drugs 2016, 14, 153. [CrossRef] [PubMed]

24. Arias, M.; Hilchie, A.L.; Haney, E.F.; Bolscher, J.G.; Hyndman, M.E.; Hancock, R.E.; Vogel, H.J. Anticancer activities of bovine and human lactoferricin-derived peptides. Biochem. Cell Biol. 2017, 95, 91-98.

25. Chalamaiah, M.; Yu, W.; Wu, J. Immunomodulatory and anticancer protein hydrolysates (peptides) from food proteins: A review. Food Chem. 2018, 245, 205-222.

26. Guedes, J.P.; Pereira, C.S.; Rodrigues, L.R.; Cortereal, M. Bovine milk lactoferrin selectively kills highly metastatic prostate cancer PC-3 and osteosarcoma MG-63 cells in vitro. Front Oncol. 2018, 8, 1-12.

27. Tomita, M.; Wakabayashi, H.; Shin, K.; Yamauchi, K.; Yaeshima, T.; Iwatsuki, K. Twenty-five years of research on bovine lactoferrin applications. Biochimie 2009, 91, 52-57. [CrossRef] [PubMed]

28. Freiburghaus, C.; Janicke, B.; Lindmark-Mansson, H.; Oredsson, S.M.; Paulsson, M.A. Lactoferricin treatment decreases the rate of cell proliferation of a human colon cancer cell line. J. Dairy Sci. 2009, 92, 2477-2484. [CrossRef]

29. Farhan, M.; Khan, H.Y.; Oves, M.; Al-Harrasi, A.; Rehmani, N.; Arif, H.; Hadi, S.M.; Ahmad, A. Cancer therapy by catechins involves redox cycling of copper ions and generation of reactive oxygen species. Toxins 2016, 8, 37. [CrossRef] [PubMed]

30. Farhan, M.; Oves, M.; Chibber, S.; Hadi, S.M.; Ahmad, A. Mobilization of nuclear copper by green tea polyphenol epicatechin-3-gallate and subsequent prooxidant breakage of cellular DNA: implications for cancer chemotherapy. Int. J. Mol. Sci. 2017, 18, 34. [CrossRef]

31. Amin, A.R.; Kucuk, O.; Khuri, F.R.; Shin, D.M. Perspectives for cancer prevention with natural compounds. J. Clin. Oncol. 2009, 27, 2712-2725. [CrossRef] [PubMed]

32. Mao, X.Y.; Gu, J.N.; Sun, Y.; Xu, S.P.; Zhang, X.Y.; Yang, H.Y.; Ren, F.Z. Anti-proliferative and anti-tumour effect of active components in donkey milk on A549 human lung cancer cells. Int. Dairy J. 2009, 19, 703-708. [CrossRef]

33. Yang, J.I.; Tang, J.Y.; Liu, Y.S.; Wang, H.R.; Lee, S.Y.; Yen, C.Y.; Chang, H.W. Roe protein hydrolysates of giant grouper (Epinephelus Lanceolatus) inhibit cell proliferation of oral cancer cells involving apoptosis and oxidative stress. Biomed. Res. Int. 2016, 23, 1-12. [CrossRef]

34. Ouyang, L.; Shi, Z.; Zhao, S.; Wang, F.T.; Zhou, T.T.; Liu, B.; Bao, J.K. Programmed cell death pathways in cancer: a review of apoptosis, autophagy and programmed necrosis. Cell Proliferat. 2012, 45, 487-498. [CrossRef]

35. Hung, C.C.; Yang, Y.H.; Kuo, P.F.; Hsu, K.C. Protein hydrolysates from tuna cooking juice inhibit cell growth and induce apoptosis of human breast cancer cell line MCF-7. J. Funct. Foods 2014, 11, 563-570.

36. Kluck, R.M.; Bossy-Wetzel, E.; Green, D.R.; Newmeyer, D.D. The release of cytochrome c from mitochondria: a primary site for Bcl-2 regulation of apoptosis. Science 1997, 275, 1132-1136. [CrossRef]

37. Hollstein, M.; Sidransky, D.; Vogelstein, B.; Harris, C.C. P53 mutations in human cancers. Science 1991, 253, 9-53.

38. Donovan, M.; Cotter, T.G. Control of mitochondrial integrity by Bcl-2 family members and caspase-independent cell death. Bioch. Bioph. Acta 2004, 1644, 133-147. [CrossRef]

39. Yang, T.; Zhu, H.; Zhou, H.; Lin, Q.L.; Li, W.J.; Liu, J.W. Rice protein hydrolysate attenuates hydrogen peroxide induced apoptosis of myocardiocytes H9c2 through the Bcl-2/Bax pathway. Food Res. Int. 2012, 48, 736-741. [CrossRef]

40. Wang, L.; Zhang, J.; Yuan, Q.; Xie, H.; Shi, J.; Ju, X. Separation and purification of an anti-tumor peptide from rapeseed (Brassica campestris L.) and the effect on cell apoptosis. Food Funct. 2016, 7, 2239-2248. [CrossRef]

41. Dai, F.; Wang, Q.; Fan, G.J.; Du, Y.T.; Zhou, B. Ros-deriven and preferential killing of HepG2 over L-02 cells by a short-term cooperation of $\mathrm{Cu}(\mathrm{II})$ and a catechol-type reveratrol analog. Food Chem. 2018, 250, 213-220. [CrossRef] [PubMed]

42. Qi, X.M.; He, L.L.; Zhong, H.Y.; Distelhors, C.W. Baculovirus p35 and z-VAD-fmk inhibit thapsigargin-induced apoptosis of breast cancer cells. Oncogene 1997, 15, 1207-1212. [CrossRef] [PubMed]

43. Bellamy, W.; Takase, M.; Wakabayashi, H.; Kawase, K.; Tomita, M. Antibacterial spectrum of lactoferricin B, a potent bactericidal peptide derived from the $\mathrm{N}$-terminal region of bovine lactoferrin. J. Appl. Bacterial 1992, 73, 472-479. [CrossRef]

44. AOAC. Official Methods of Analysis of Association of Official Analytical Chemists International, 18th ed.; AOAC International: Gaithersburg, MD, USA, 2005. 
45. Church, F.C.; Swaisgood, H.E.; Porter, D.H.; Catignani, G.L. Spectrophotometric assay using $o$-phthaldialdehyde for determination of proteolysis in milk and isolated milk proteins. J. Dairy Sci. 1983, 66, 1219-1227. [CrossRef]

46. Nagy, A.; Marciniak-Darmochwal, K.; Krawczuk, S.; Gelencser, E. Influence of glycation and pepsin hydrolysis on immunoreactivity of albumin/globulin fraction of herbicide resistant wheat line. Czech J. Food Sci. 2009, 27, 320-329. [CrossRef]

Sample Availability: Samples of the compounds bovine lactoferrin and bovine lactoferrin hydrolysate are available from the authors.

(C) 2019 by the authors. Licensee MDPI, Basel, Switzerland. This article is an open access article distributed under the terms and conditions of the Creative Commons Attribution (CC BY) license (http:/ / creativecommons.org/licenses/by/4.0/). 